\title{
Penerapan Penjatuhan Hukuman Kebiri Kimia Serta Tata Cara Eksekusinya pada Pelaku Kejahatan Pelecehan Seksual terhadap Anak
}

\author{
Nashru Nazar Rosyidi ${ }^{1 *}$, Oci Senjaya ${ }^{2}$ \\ ${ }^{1,2}$ Fakultas Hukum Universitas Singaperbangsa Karawang \\ Jl. Hs Ronggo Waluyo Kecamatan Telukjambe Timur Kabupaten Karawang \\ *Correspondence email: nashrunazar@gmail.com
}

\begin{abstract}
Abstrak. Dewasa ini semakin marak terjadinya kejahatan pelecehan seksual terhadap anak di Indonesia. Anak sebagaimana mestinya harus dilindungi pemerintah agar kelak menjadi generasi penerus bangsa. Pada tahun 2019 PN Mojokerto memutus perkara dengan nomor register 69/Pid.Sus/2019/PN.Mjk dengan amar putusan hukuman kebiri kepada Terdakwa Aris (20) yang terbukti melakukan kejahatan pelecehan seksual terhadap anak dan putusan tersebut merupakan putusan pertama di Indonesia menerapkan penjatuhan hukuman kebiri kimia bagi pelaku kejahatan pelecehan seksual terhadap anak. Penulisan ini menggunakan metode yuridis-normatif dimana melihat data empiris sebagai acuan dari penulisan jurnal ini. Bagi beberapa pihak hukuman kebiri kimia dinilai efektif untuk menghukum pelaku kejahatan pelecehan seksual terhadap anak agar menjadi hal yang menakutkan bagi pelaku kejahatan pelecehan seksual lainnya. Hal tersebut termasuk dalam kategori teori tujuan pemidanaan agar menciptakan ketentraman dan ketertiban dalam masyarakat. Perppu Nomor 1 Tahun 2016 merupakan dasar hukum penerapan hukuman kebiri kimia. Akan tetapi, timbul banyaknya pro dan kontra terhadap hukuman kebiri. Salah satu hal yang menimbulkan kontra adalah bertentangan dengan ratifikasi mengenai Hak Asasi Manusia. Mengingat Indonesia adalah negara hukum yang dimana dalam negara hukum wajib untuk melindungi dan menjaminan Hak Asasi Manusia sesuai dengan yang tertuang dalam Pasal 28I UUD NRI 1945.
\end{abstract}

Kata kunci: Kebiri Kimia; Kejahatan Seksual; Hak Asasi Manusia

\begin{abstract}
Nowadays, there are more and more crimes of child sexual abuse in Indonesia. Children should be protected by the government in order to become the nation's next generation. In 2019, the Mojokerto District Court sentenced the defendant Aris (20) who was convicted of a crime of sexual abuse against a child and this verdict was the first verdict in Indonesia to impose chemical castration on perpetrators of crimes of sexual abuse against children. This writing uses the juridical-normative method which looks at empirical data as a reference for writing this journal. For some parties, chemical castration punishment is considered effective in punishing perpetrators of crimes of child sexual abuse so that it becomes a frightening thing for other perpetrators of sexual abuse crimes. This is included in the category of the theory of the purpose of punishment in order to create order and order in society. Perppu Number 1 of 2016 is the legal basis for the application of chemical castration punishment. However, there are many pros and cons to castration. One of the things that has created contra is contrary to the ratification of human rights. Considering that Indonesia is a state based on the rule of law, which is obliged to protect human rights guarantees as stated in Article 28 I of the 1945 Constitution of the Republic of Indonesia.
\end{abstract}

Keywords: Chemical Castration; Sexual Crime; Human Rights.

\section{PENDAHULUAN}

Dewasa ini Indonesia semakin hari menjadi negara yang darurat pelecehan maupun kejahatan pelecehan seksual terhadap anak. Dari tahun ke tahun kasus kejahatan pelecehan seksual terhadap anak selalu meningkat sehingga menjadi urgensi tersendiri bagi aparat penegak hukum untuk menindak secara tegas. Mengingat anak merupakan aset bangsa untuk kedepannya sehingga harus dijaga secara tumbuh kembangnya agar kelak menjadi penerus bangsa yang dapat meregenerasi kehidupan dalam masyarakat.

Upaya untuk mewujudkan masyarakat Indonesia yang sejahtera, adil, dan makmur yang merata bagi kehidupan bermasyarakat berdasarkan Pancasila dan Undang-Undang Dasar 1945. Presiden Republik Indonesia Jokowi dengan tegas menyatakan dan mendukung pemberian hukuman kebiri kimia bagi pelaku kejahatan pelecehan seksual terhadap anak di bawah umur, karna akibat yang ditimbulkan apabila dibiarkan secara bekerlanjutan dapat berdampak semakin buruk bagi kelangsungan berkehidupan dalam masyarakat terutama bagi tumbuh kembang anak. Dalam hal ini dapat berefek buruk bagi generasi muda Bangsa Indonesia. Presiden Jokowi menyetujui pemberian hukuman tambahan bagi para pelaku kejahatan seksual terhadap anak mengenai hukuman kebiri kimia.

Untuk pertama kalinya hukuman kebiri kimia diterapkan di Indonesia diberikan oleh hakim kepada terdakwa yang bernama Aris pemerkosa 9 anak di Mojokerto, Jawa Timur. Hukuman yang diharapkan dapat memberikan efek jera kepada pelaku dan juga masyarakat sekitar agar tidak melakukan kejahatan pelecehan seksual terhadap anak. Hal ini merupakan bentuk keseriusan negara yang telah mengategorikan kekerasan seksual kepada anak sebagai kejahatan 
luar biasa atau extraordinary crimes yang setara dengan kejahatan narkoba, terorisme, dan korupsi. ${ }^{1}$

Kejahatan yang dilakukan Aris (20) seorang pemuda asal Mojokerto, Jawa Timur tergolong sangat serius. Berdasarkan fakta-fakta yang terungkap dalam persidangan, 9 korban rata-rata masih duduk di bangku Taman Kanakkanak (TK). Bermula saat sedang dalam perjalanan pulang kerja, ia bertemu degan korban yang sedang bermain sendirian didepan rumah. Kemudian saat terdakwa Aris timbul niat untuk mengajak korban agar ikut bersamanya ke sebuah rumah kosong yang tak jauh dari tempatnya hingga akhirnya terdakwa Aris membekap mulut korban dan memperkosa korban sehingga menyebabkan alat kelamin korban berdarah. Hasil visum menunjukkan korban mengalami robek dan pendarahan pada alat kelaminnya.

Saat proses penyidikan polisi ternyata terdakwa Aris bukan hanya sekali melakukannya, akan tetapi sudah 11 kali melakukannya kepada anak-anak kecil yang rata rata menduduki di bangku Taman Kanak-kanak. Hingga akhirnya perbuatan terdakwa Aris terbukti bersalah melakukan kejahatan seksual terhadap 9 orang anak. Aris telah dinyatakan bersalah berdasarkan putusan hakim kaarena melanggar Pasal 76 D juncto Pasal 81 ayat (2) UndangUndang RI Nomor 23 Tahun 2002 tentang Perlindungan Anak juncto Undang-Undang Nomor 17 Tahun 2016 tentang Penetapan Peraturan Perundang-Undangan 1 Tahun 2016 tentang Perubahan Kedua Atas Undang-Undang 23 Tahun 2002 tentang Perlindungan Anak Menjadi Undang-Undang.

Ketika itu Jaksa Penuntut Umum pada persidangan di Pengadilan Negeri Mojokerto menuntut terdakwa dengan hukuman penjara 17 tahun dan denda Rp. 100.000.000,- subsider 6 bulan kurungan apabila tidak membayar denda. Kemudian Majelis Hakim mempertimbangkan dan memberikan putusan yaitu hukuman kebiri kimia dan hukuman penjara selama 12 tahun dan denda Rp. 100.000.000,- subsider 6 bulan kurunganapabila tidak membayar denda hal tersebut tercantum dalam putusan hakim putusan nomor 69/Pid.Sus/2019/PN.Mjk.

Hal tersebut bukan berarti tanpa dasar hukum yang pasti, bahkan sudah disahkan Peraturan Pemerintah Pengganti Undang-Undang (Perppu) Nomor 1 Tahun 2016 tentang Perubahan Kedua Atas Undang-Undang Nomor 23 Tahun 2002 tentang Perlindungan Anak. Perppu Nomor 1 tahun 2016 ini kemudian disahkan menjadi UndangUndang Nomor 17 Tahun 2016 tanggal 9 November 2016 tentang Penetapan Perppu Nomor 1 Tahun 2016 tentang Perubahan Kedua Atas Undang-Undang Nomor 23 Tahun 2002 tentang Perlindungan Anak Menjadi Undang-Undang tepatnya pada Pasal 81 ayat (5) dan 81 ayat (7) yang mengatur mengenai pemberatan hukuman bagi pelaku kejahatan seksual terhadap anak yaitu hukuman pidana mati, seumur hidup, dan maksimal 20 tahun penjara serta pidana tambahan berupa pengumuman identitas pelaku. Selanjutnya pelaku juga dapat dikenai tindakan berupa kebiri kimia dan pemasangan pendeteksi elektronik. ${ }^{2}$

Pada kasus terdakwa Aris, muncul pro dan kontra dalam masyarakat atas putusan hakim mengenai hukuman kebiri kimia yang akan dilaksanakan oleh terdakwa dengan dalih melanggar esensi Hak Asasi Manusia yang telah disepakati oleh negara-negara dunia termasuk oleh negara Indonesia sendiri termasuk Komisi Nasional Hak Asasi Manusia juga berpendapat melalui komisionernya Choirul Anam mengenai hukuman kebiri kimia yang dijatuhkan oleh hakim PN Mojokerto agar ditinjau ulang berdasarkan ratifikasi ICCPR dan CAT yang telah dianut sejak lama oleh negara Indonesia, agar Indonesia tetap berkomitmen dalam hal pemidanaan melihat unsur-unsur jaminan Hak Asasi Manusia. Selain itu, pelaksanaan tindakan hukuman kebiri secara kimia juga harus memperhatikan aspek biaya tinggi dan adanya persetujuan (informed consent) dari pelaku kekerasan seksual atas tindakan hukuman kebiri kimia yang dilakukan padanya.

Di beberapa negara bagian Amerika Serikat, seperti halnya California yang merupakan negara bagian Amerika Serikat yang pertama melakukan pemberlakuan hukuman kebiri kimia bagi pelaku kejahatan seksual terhadap anak sejak tahun 1996. Sedangkan di negara bagian Florida, hukuman kebiri diberlakukan sejak tahun 1997. Lalu disusuli dengan negara-negara bagian lainnya seperti Georgia, Lowa, Louisiana, Montana, Oregon, Texas dan Winconsin. Selain itu, hukuman kebiri kimiawi juga diberlakukan di negara-negara Eropa seperti di Polandia, Inggris, Estonia dan Makedonia. Lalu ada negara Korea Selatan dan Rusia yang memberlakukan pidana kebiri juga bagi pelaku kejahatan seksual terhadap anak. ${ }^{3}$

Masyarakat luas sedikit banyaknya percaya apabila adanya hukuman kebiri kimia tersebut dilaksanakan atau diterapkan akan menjadi hal yang menakutkan bagi para pelaku kejahatan pelecehan seksual terhadap anak dan meminimalisir adanya kejahatan tersebut. Karena akibat dari kejahatan pelecehan seksual terhadap anak sangat mengkhawatirkan bagi anak dan tidak dipungkiri bahwa anak yang menjadi korban mendapatkan trauma yang sangat hebat hingga menghancurkan hidupnya sebagai manusia dan serasa tidak mampu untuk melanjutkan hidupnya. Akan

1 Dilansir pada https://nasional.republika.co.id/berita/pww9mi384/hukum-kebiri-diterapkan-fahira-ini-peringatan-keras ; diakses tanggal 22 November 2020.

${ }^{2}$ Nuzul Qur'aini Mardiya, Penerapan Hukuman Kebiri Kimia Bagi Pelaku Kekerasan Seksual, Jurnal Konstitusi, Volume 14, Nomor 1, Maret 2017.

${ }^{3}$ Dilansir pada http://www.tribunnews.com/internasional/2016/05/27/ini-negara-negara-yang-berlakukan-hukuman- kebiribagi-pelaku-pelecehan; diakses tanggal 22 November 2020 
tetapi hukuman kebiri kimia tersebut belum tentu berbanding lurus dengan tujuan pemidanaan dalam hukum positif di Indonesia dan perlindungan Hak Asasi Manusia.

Tujuan pemidanaan sebenarnya bukan sebuah hal pemikiran yang baru, melainkan sedikit banyaknya telah mendapat pengaruh dari pemikir-pemikir pada beberapa abad yang lalu, yaitu tentang dasar pembenaran (Recht Vaardigings Ground) dari suatu pemidanaan. ${ }^{4}$

Pada dasarnya terdapat tiga pokok pemikiran tentang tujuan yang ingin dicapai dalam suatu pemidanaan, yaitu mencakup hal-hal sebagai berikut :

1. Memperbaiki pribadi dari penjahatnya itu sendiri;

2. Membuat orang menjadi jera melakukan kejahatan-kejahatan;

3. Membuat penjahat-penjahat tertentu menjadi tidak mampu untuk melakukan kejahatan-kejahatan yang lain, yakni penjahat-penjahat yang dengan cara-cara lain sudah tidak dapat diperbaiki kembali. ${ }^{5}$

Andi Hamzah menyebutkan mengenai teori tujuan pemidanaan berpendapat bahwa Pembalasan (Vergelding) oleh banyak orang dikemukakan sebagai alasan untuk memidana suatu kejahatan, kepuasan hatilah yang dikejar. Apabila ada seseorang oknum atau pelaku yang langsung merasakan atau menderita karena kejahatan, maka kepuasan itu ada pada oknum. Dalam hal pembunuhan, kepuasan hati ada pada keluarga korban khususnya dan masyarakat umumnya. ${ }^{6}$

Adapun menurut teori telatif dalam tujuan pemidanaan yang dikemukakan oleh Prof Muladi dan Barda Nawawi Arief, menyatakan bahwa pidana dijatuhkan bukan qula peccatum est atau karena orang berbuat kejahatan, melainkan untuk ne peccatum atau supaya orang jangan melakukan kejahatan. ${ }^{7}$ mengenai dengan hal tersebut, tujuan pemidanaan terbagi menjadi beberapa pendapat, yaitu :

1. Tujuan pidana adalah untuk menentramkan masyarakat yang gelisah akibat dari telah terjadinya kejahatan.

2. Tujuan pidana adalah untuk mencegah terjadinya kejahatan yang dapat dibagikan atas pencegahan umum (general preventie) dan pencegahan khusus (special preventie), yang antara lain yaitu :

a. Pencegahan Umum (general preventie)

Pencegahan umum didasarkan pada pikiran bahwa pidana itu dimaksudkan untuk mencegah setiap orang yang akan melakukan kejahatan. Untuk mencapai maksud dan tujuan tersebut terdapat beberapa cara, yaitu:

1) Dengan mengadakan ancaman pidana yang cukup berat untuk menakut-nakuti orang-orang yang tidak melakukan kejahatan

2) Dengan menjatuhkan pidana dan melaksanakan pidana yang dilakukan dengan cara yang kejam sekali dengan dipertontonkan kepada umum, sehingga setiap orang akan merasa takut untuk melakukan kejahatan. ${ }^{8}$

b. Pencegahan Khusus (special preventie)

Pencegahan khusus ini didasarkan pada pikiran bahwa pidana itu dimaksudkan agar orang yang telah melakukan kejahatan tidak mengulanginya kembali. Berikut prevensi khusus mengenai suatu tindak pidana menurut Van Hammel, antara lain yaitu :

1) Pidana itu harus memuat unsur-unsur menakutkan supaya mencegah penjahat yang mempunyai kesempatan untuk tidak melaksanakan niat buruknya.

2) Pidana itu harus mempunyai unsur unruk memperbaiki terpidana.

3) Pidana mempunyai unsur membinasakan penjahat yang tidak mungkin diperbaiki.

4) Tujuan satu-satunya suatu pidana ialah mempertahankan ketertiban hukum. ${ }^{9}$

Sehingga secara tidak langsung tujuan pemidanaan adalah upaya untuk memperbaiki kerusakan individual dan sosial (individual and social damages) yang diakibatkan oleh pelaku kejahatan. Hal tersebut terdiri dari seperangkat tujuan pemidanaan yang harus dipenuhi dengan catatan bahwa tujuan dan makna yang merupakan titik berat sifatnya adalah kasuistis. Perangkat tujuan pemidanaan yang dimaksud adalah pencegahan umum, perlindungan masyarakat, memelihara solidaritas masyarakat, dan pengimbalan/pengimbangan ${ }^{10}$

Dalam hukum positif di Indonesia aturan mengenai pemidanaan diatur dalam Pasal 10 KUHP yang berisikan sebagai berikut:

${ }^{4}$ Gunadi, dkk, Penologi dan Pemasyarakatan, (Jakarta : PT. Adhi Sarana Nusantara, 2018), hlm. 44.

${ }^{5}$ Muladi, dkk, Teori-Teori dan Kebijakan Pidana, (Bandung : Alumni), 2008.

${ }^{6}$ Otje Salman, dkk, Teori Hukum (Mengingat, Mengumpulkan, dan Membuka Kembali), (Bandung : Refika Aditama, 2005), hlm. 99.

\footnotetext{
${ }^{7}$ Ibid, hlm. 23

${ }^{8}$ Siswanto Sunarso, Penegakan Hukum dalam Kajian Sosiologis, (Jakarta : Raja Grafindo Persada, 2005), hlm. 136.

${ }^{9}$ Tolib Setiady, Pokok-Pokok Hukum Penintesier Indonesia, (Bandung : Alfabet, 2009).

${ }^{10}$ Otje Salman, Op Cit, hlm. 103.
} 


\section{a. Pidana Pokok: \\ 1. Pidana mati; \\ 2. Pidana penjara; \\ 3. Pidana kurungan; \\ 4. Pidana denda; \\ 5. Pidana tutupan.}

b. Pidana Tambahan:

1. Pencabutan hak-hak tertentu;

2. Perampasan barang-barang tertentu;

3. Pengumuman putusan hakim

Berdasarkan hal tersebut posisi hukuman kebiri kimia merupakan masuk dalam klasifikasi hukuman tambahan yang diatur lebih lanjut dalam tercantum dalam Undang-Undang Nomor 17 Tahun 2016 tentang Penetapan Peraturan Pemerintah Pengganti Undang-Undang Nomor 1 Tahun 2016 tentang Perubahan Kedua atas Undang-Undang Nomor 23 Tahun 2002 tentang Perlindungan Anak yang telah disahkan menjadi undang-undang pada tanggal 9 November 2016.

\section{METODE}

Metode penulisan yang dilakukan oleh penulis yaitu dengan cara yuridis-normatif dengan melihat data empiris yang telah terjadi. Kemudian menggunakan data sekunder sebagai data awalnya, dilanjutkan dengan data primer, Meneliti efektivitas suatu Undang-Undang hingga putusan hakim. Penelitian ini ingin mencari hubungan atau korelasi antara berbagai gejala atau variabel sebagai alat penunjang data yang terdiri dari studi dokumen dan pengamatan. Dengan jenis penelitian kualitatif, dimana penelitian kualitatif mengkaji perspektif dengan strategi-strategi yang bersifat fleksibel. Penelitian kualitatif ditujukan untuk memahami fenomena-fenomena sosial dari sudut pandang penulis.

\section{HASIL DAN PEMBAHASAN}

\section{Penerapan Penjatuhan Hukuman Kebiri Kimia Pada Pelaku Kejahatan Pelecehan Seksual Terhadap Anak di Indonesia}

Kejahatan kekerasan seksual terhadap anak adalah apabila seseorang menggunakan obyek anak untuk mendapatkan kenikmatan atau kepuasan seksual bagi pribadinya. Tidak terbatas pada hubungan seksual saja, akan tetapi terdapat juga tindakan-tindakan yang mengarah kepada aktifitas seksual terhadap anak-anak, seperti menyentuh tubuh anak secara seksual terutama bagian alat vital, segala bentuk penetrasi seksual (termasuk penetrasi melalui mulut anak menggunakan benda atau anggota tubuh), membuat atau memaksa anak terlibat dalam aktifitas seksual (secara sengaja melakukan aktifitas seksual di hadapan anak atau tidak melindungi dan mencegah anak menyaksikan aktifitas seksual yang dilakukan orang lain), membuat, mendistribusikan, serta menampilkan gambar-gambar atau video yang mengandung adegan anak-anak dalam tindakan tidak senonoh, serta memperlihatkan kepada anak, gambar, foto atau film yang menampilkan aktivitas seksual.

Kejahatan Kekerasan seksual terhadap anak termasuk kejahatan luar biasa ataun extraordinary crimes yang semakin meningkat dari waktu ke waktu dan secara signifikan mengancam dan membahayakan jiwa anak, merusak kehidupan pribadi dan tumbuh kembang anak, serta mengganggu rasa kenyamanan, ketentraman, keamanan, dan ketertiban masyarakat luas. Masuknya kekerasan seksual terhadap anak ke dalam bagian kejahatan luar biasa (extraordinary crimes) tidak dipungkiri dilakukannya juga penegakkan hukum (enforcement law) yang luar biasa.

Kejahatan kekerasan seksual terhadap anak dapat mengancam siapa saja dan dimana saja, maka dari itu diperlukan juga pengawasan secara ketat agar melindungi anak dari hal-hal yang bersifat kekerasan seksual terhadapnya guna kebaikan dan kelangsungan hidup si anak. Secara bersama-sama pemerintah maupun keluarga mempunyai peranan penting bagi perlindungan untuk anak.

Peraturan Pemerintah pengganti Undang-Undang Nomor 1 Tahun 2016 tentang perubahan kedua UndangUndang Nomor 23 Tahun 2002 tentang Perlindungan Anak. Disahkannya Peppu ini semata-mata bahwa sanksi pidana yang dijatuhkan bagi pelaku kekerasan seksual terhadap anak belum memberikan efek jera dan belum mampu mencegah secara maksimal mengenai terjadinya kekerasan seksual terhadap anak, oleh karena itu sangat diperlukan perlu segera mengubah Undang-Undang Nomor 23 Tahun 2002 tentang Perlindungan Anak sebagaimana telah diubah dengan Undang-Undang Nomor 35 Tahun 2014 tentang Perubahan atas Undang-Undang Nomor 23 Tahun 2002 tentang Perlindungan Anak dan juga Undang-Undang Nomor 17 Tahun 2016 tentang Penetapan Peraturan PerundangUndangan 1 Tahun 2016 tentang Perubahan Kedua Atas Undang-Undang 23 Tahun 2002 tentang Perlindungan Anak Menjadi Undang-Undang. 
Perppu Nomor 1 Tahun 2016 ini sangat memberatkan sanksi bagi pelaku kejahatan seksual yakni menambah pidana pokok berupa pidana mati dan seumur hidup serta pidana tambahan berupa pengumuman identitas pelaku. Selain itu, ada penambahan ketentuan mengenai tindakan berupa kebiri kimia, pemasangan alat pendeteksi elektronik, dan rehabilitasi. Dengan kata lain kebiri kimia merupakan tindakan yang dilaksanakan selama dan/atau setelah terpidana menjalani pidana pokok. Kebiri adalah tindakan bedah dan atau menggunakan bahan kimia yang bertujuan untuk menghilangkan fungsi testis pada jantan atau fungsi ovarium pada betina.

Ada dua macam teknik kebiri yang diterapkan, yaitu kebiri fisik dan kebiri kimiawi. Kebiri fisik dilakukan dengan cara mengamputasi organ seks eksternal pemerkosa sehingga membuat pelaku kekurangan hormon testosteron. Kurangnya hormon ini akan banyak mengurangi dorongan seksual bagi pelaku yang dilakukannya kebiri kimia.

Kebiri kimia tidak dilakukan dengan mengamputasi testis, tetapi dengan cara memasukkan zat kimia antiandrogen ke tubuh seseorang supaya produksi hormon testosteron di tubuh mereka berkurang. Hasil akhirnya sama dengan kebiri fisik, yakni menghilangkan libido atau hasrat seksual atau kemampuan ereksi. Hukuman kebiri kimia menimbulkan efek yang negatif berupa penuaan dini pada tubuh orang yang dilakukannya kebiri kimia. ${ }^{11}$

Cairan antiandrogen diketahui akan mengurangi kepadatan tulang sehingga risiko tulang keropos atau osteoporosis meningkat. Cairan antiandrogen juga mengurangi massa otot sehingga memperbesar kesempatan tubuh menumpuk lemak yang pada gilirannya meningkatkan risiko penyakit jantung dan pembuluh darah. Berbeda dengan kebiri fisik, kebiri kimia tidak bersifat permanen. Artinya, jika pemberian cairan antiandrogen dihentikan, maka efeknya juga akan berhenti, dan pemerkosa akan mendapatkan lagi fungsi seksualnya, baik berupa hasrat seksual, maupun kemampuan ereksi.

Sehingga penerapan hukuman kebiri kimia diperlukan penelitian lebih lanjut terkait hukuman kebiri kimia bagi pelaku kejahatan seksual terhadap anak. Pemerintah seharusnya mempunya kajian lebih lanjut terkait penelitian medis terkait dengan hukman kebiri kimia. Karena terdapat hal-hal yang dianggap merampas Hak Asasi Manusia dalam pemidanaan yang dijalankan oleh pelaku kejahatan seksual terhadap anak. Dalam hal ini hukuman kebiri kimia meskipun sudah terdapat aturan yang lebih lanjut tetapi tidak menutup kemungkinan pemerintah terus melakukan penelitian medis mengenai hukuman kebiri kimia.

\section{Tata Cara Pelaksanaan Hukuman Kebiri Kimia Berdasarkan Peraturan Pemerintah Nomor 70 Tahun 2020 Tentang Tata Cara Pelaksanaan Tindakan Kebiri Kimia}

Bahwa pada tanggal 7 Desember 2020 pemerintah mengeluarkan Peraturan Pemerintah Nomor 70 Tahun 2020 tentang Tata Cara Pelaksanaan Tindakan Kebiri Kimia, Pemasangan Alat Pendeteksi Elektronik, Rehabilitasi, dan Pengumuman Identitas Pelaku Kekerasan Seksual Terhadap Anak (selanjutnya disingkat PP No. 70 Tahun 2020). Pertimbangan pemerintah mengeluarkan PP No. 70 Tahun 2020 adalah untuk mengatasi kekerasan seksual terhadap anak, memberi efek jera terhadap pelaku, dan mencegah terjadinya kekerasan seksual terhadap anak serta untuk melaksanakan ketentuan Pasal 81A ayat (4) dan Pasal 82 ayat (3) UU No. 17 Tahun 2016 tentang Penetapan Perppu No. 1 Tahun 2016 tentang Perubahan Kedua atas UU No. 23 Tahun 2002 tentang Perlindungan Anak menjadi Undang-Undang.

Berdasarkan Pasal 1 ayat (2) PP No. 70 Tahun 2020 yang didefinisikan mengenai Tindakan Kebiri Kimia adalah pemberian zat kimia melalui penyuntikan atau metode lain, yang dilakukan kepada pelaku yang pernak dipidana karena melakukan kekerasan atau ancaman kekerasan memaksa Anak melakukan persetubuhan dengannya atau dengan orang lain sehingga menimbulkan korban lebih dari satu orang yang mengakibatkan luka berat, gangguan jiwa, penyakit menular, terganggunya atau hilangnya fungsi reproduksi, dan/atau korban meninggal dunia untuk menekan hasrat seksual berlebih yang disertai rehabilitasi.

Kemudian berdasarkan PP No. 70 Tahun 2020 juga menyebutkan bahwasannya tindakan kebiri kimia dikenakan terhadap pelaku persetubuhan berdasarkan putusan pengadilan yang telah berkekuatan hukum tetap. Serta pelaksanannya dilaksanakan atas perintah jaksa setelah berkoordinasi dengan kementrian yang menyelenggarakan urusan pemerintah di bidang kesehatan, kementrian yang menyelenggarakan di bidang hukum, dan kementrian yang menyelenggarakan di bidang sosial.

Tata cara pelaksanan hukuman kebiri kimia, berdasarkan Pasal 5 dan Pasal 6 paling lama dikenakan dalam jangka waktu 2 (dua) tahun dan berdasarkan beberapa tahapan, yaitu; a. Penilaian Klinis, b. Kesimpulan, dan c. Pelaksanaan. Penilaian klinis dilakukan oleh tim yang terdiri dari petugas yang memiliki kompetensi di bidang medis dan psikiatri. Adapun penilaian klinis meliputi beberapa hal, yang diantaranya adalah; a. wawancara klinis dan psikiatri, b. pemeriksaan fisik, dan c. pemeriksaan penunjang. Setelah penilaian klini dilakukan, kemudian dilakukannya kesimpulan yamg memuat hasil penilaian klinis untuk memastikan pelaku persetubhan layak atau

11 https://www.cnnindonesia.com/gaya-hidup/20210104193518-255-589391/mengenal-kebiri-kimia-menghilangkanfungsi-testis-dan-libido (diakses pada tanggal 26 maret 2021 pukul 1:28 Wib) 
tidaknya untuk dikenakan tindakan hukuman kebiri kimia. Setelah kesimpulan dilakukan, rangkaian selanjutnya adalah Pelaksanaan hukuman kebiri kimia. Adapun yang dalam jangka waktu paling lambat 7 hari kerja sejak diterimanya kesimpulan, jaksa dapat memerintahkan dokter untuk melakukan pelaksanaan pelaksanaan tindakan hukuman kebiri kimia. Kemudian pelaksanannya juga dilakukan setelah terpidana telah menjalani pidana pokok dan dilakukan di rumah sakit milik pemerintah atau rumah sakit daerah yang ditunjuk. Pelaksanaan hukuman kebiri kimia juga dihadiri oleh jaksa, perwakilan dari kementrian yang menyelenggarakan urusan dibidang hukum, kesehatan, dan sosial serta dituangkan dalam bentuk berita acara dan diberitahukan kepada korban atau keluarga korban bahwasannya telah dilakukan pelaksaan hukuman kebiri kimia.

Pasal 10 PP No. 70 Tahun 2020 menjelaskan mengenai apabila terpidana tidak memenuhi syarat penilaian klinis dan kesimpulan. Adapun apabila terpidana dinyatakan tidak layak untuk dilakukannya hukuman kebiri kimia, maka pelaksanaan penundaan tindakan hukum kebiri kimia ditundak paling lama 6 (enam) bulan. Kemudian dalam hal penilaian klinis ulang dan kesimpulan terpidana tetap dinyatakan tidak layak, maka jaksa memberitahukan secara tertulis kepada pengadilan yang memutus perkara pada tingkat pertama dengan melampirkan hasil penilaian klinis ulang dan kesimpulan ulang.

\section{Tujuan Pemidanaan Berdasarkan Perspektif Hak Asasi Manusia Dalam Penjatuhan Hukuman Kebiri Kimia}

Masalah pokok dalam hukum pidana berkenaan dengan tiga hal, yaitu: masalah perbuatan atau tindakan pidana, masalah kesalahan atau pertanggungjawaban pidana, serta masalah pemidanaan. Kaitannya dengan tiga masalah pokok hukum pidana tersebut, ilmu hukum pidana yang dikembangkan dewasa ini lebih banyak membicarakan masalah-masalah yang bersifat dogmatik hukum pidana daripada sanksi pidana. Pembahasan tentang sanksi pidana yang bersifat memperkokoh norma hukum pidana belum banyak dilakukan, sehingga pembahasan seluruh isi hukum pidana dirasakan masih belum serasi. Andi Hamzah juga menyatakan bahwa perbuatan pidana dan pemidanaan bukan hanya berkaitan erat dengan hukum pidana, tetapi menjadi permasalahan inti mengenai hukum pidana. ${ }^{12}$

Sedangkan dalam hal masalah pidana dan pemidanaan menurut Bambang Purnomo dianggap merupakan suatu bentuk yang tak banyak diketahui, sehingga pembahasan tentang hal tersebut menyoroti pidana pada umumnya dan pidana penjara pada khususnya kurang mendapat perhatian. Oleh karena itu banyak dipersoalkan dalam ilmu hukum pidana terletak di bidang asas-asas hukum pidana mengenai perbuatan pidana dan pertanggungjawaban pidana, yang pada dasarnya terletak di luar bidang pidana dan sistem pemidanaan. ${ }^{13}$

Hal ini tampak pada tujuan pemidanaan, yaitu sebagai sarana pencegahan, pembinaan dan pemulihan ketertiban masyarakat, serta sarana pembebasan rasa bersalah pelaku tindak pidana, antara lain tujuan pemidanaan, yaitu:

1. Pemidanaan bertujuan :

a. Mencegah dilakukannya perbuatan tindak pidana dengan menegakan norma hukum demi melindungi masyarakat;

b. Memasyarakatkan terpidana dengan mengadakan pembinaan sehingga menjadi orang yang baik dan berguna bagi masyarakat luas;

c. Menyelesaikan konflik yang ditimbulkan karena perbuatan tindak pidana, memulihkan keseimbangan dan mendatangkan rasa damai dalam masyarakat, dan;

d. Membebaskan rasa bersalah pada terpidana.

2. Pemidanaan tidak dimaksudkan untuk menderitakan dan merendahkan martabat manusia

3. Urutan pidana sebagaimana dimaksud pada poin 1 menentukan berat ringanya pidana

Sementara pada pidana mati merupakan pidana pokok yang bersifat khusus dan selalu diancamkan secara alternatif, antara lain:

1. Pidana tambahan terdiri atas:

a. Pencabutan hak-hak tertentu; Keduduan Pidana Kebiri Dalam Sistem Pemidanaan di Indonesia (Pasca Dikeluarkannya Undang-Undang No. 1 Tahun 2016);

b. Perampasan barang tertentu dan/atau tagihan

c. Pengumuman putusan hakim;

d. Pembayaran ganti kerugian; dan

e. Pemenuhan kewajiban adat setempat dan/atau kewajiban menurut hukum yang hidup dalam masyarakat.

2. Pidana tambahan dapat dijatuhkan bersama-sama dengan pidana pokok, sebagaimana pidana yang berdiri sendiri atau dapat dijatuhkan bersamasama dengan pidana tambahan lain.

\footnotetext{
${ }^{12}$ Andi Hamzah, Sistem Pidana dan Pemidanaan Indonesia, Jakarta, Pradnya Paramita, 1993, hlm. 9.

${ }^{13}$ Ibid, hlm. 9.
} 
3. Pidana tambahan berupa pemenuhan kewajiban adat setempat dan/atau kewajiban menurut hukum yang hidup dalam masyarakat atau pencabutan hak yang diperoleh korporasi dapat dijatuhkan walaupun tidak tercantum dalam perumusan tindak pidana.

4. Pidana tambahan untuk percobaan dan pembantuan adalah sama dengan pidana tambahan untuk tindak pidananya.

Eksekusi hukuman kebiri kimia dilaksanakan setelah pelaku menyelesaikan pidana pokok yang telah ditetapkan dalam putusan pengadilan yang ingkrah. Sanksi pidana hukuman kebiri kimia ini akan diberikan 2 (dua) tahun setelah menjalani pidana pokok dan juga diberlakukan maksimal selama 2 (dua) tahun atas keputusan dari hakim. Maka ketika masa berlaku kebiri kimia tersebut sudah mencapai maksimal 2 (dua) tahun sehingga alat reproduksi pelaku akan berfungsi kembali. Apabila pelaku dijatuhi hukuman kebiri kimia dalam pembuktian kejahatannya tersebut dibutuhkan kesaksian dari ahli yang harus memberikan keterangan tentang latar belakang pelaku hingga ia melakukan kekerasan seksual pada anak.

Disisi lain hukuman kebiri kimia didasarkan pada teori gabungan yaitu teori absolut dan relatif. Disamping itu sanksi kebiri kimia merupakan bentuk hukuman pembalasan dendam atas pihak yang merasa dirugikan yaitu anak dan juga keluarga korban. Akan tetapi disisi lain sanksi kebiri kimia merupakan upaya untuk mencegah terpidana dari kemungkinan mengulangi kekerasan seksual dimasa depan.

Seorang pelaku kejahatan pelecehan seksual terhadap anak memiliki faktor utama yang berkepanjangan dan lemahnya ikatan individu atau ikatan sosial pada masyarakat atau macetnya integrasi sosial. Faktor lainnya adalah berupa faktor internal dan faktor eksternal. Faktor internal merupakan faktor biologis, faktor kejiwaan, serta faktor moral. Sedangkan faktor eksternal merupakan faktor ekonomi, faktor sosial-budaya, serta faktor media massa. Seharusnya hukuman kebiri kimia merupakan suatu penanganan yang diberikan kepada pelaku yang diharapkan mampu untuk memulihkan pola pikir pelaku untuk tidak akan melakukan kejahatan lagi. Permasalahan utama dari seorang pelaku kekerasan seksual adalah terdapat pada masalah kejiwaannya dan bukan terdapat pada alat vitalnya. Selain itu biaya atau anggaran yang dibutuhkan didalam pelaksanaan sanksi tersebut terbilang cukup tinggi dalam pelaksanaan eksekusinya dan belum ada kepastian siapakah yang menjadi eksekutor pemberian zat antiandrogen untuk pelaku karena bagi IDI atau Ikatan Kedokteran Indonesia hal tersebut bertolak belakang dengan Kode Etik Kedokteran. Oleh karena itu, diperlukan juga eksekutor berdasarkan ketentuan undang-undang yang berlaku.

Langkah untuk mengurangi kekerasan seksual pada anak tidak bisa hanya sekedar dari tindakan represif tetapi juga dengan tindakan preventif karena apabila berpacu pada undang-undang, kekerasan seksual pada anak masih dirasa lebih merugikan terhadap korban, karena proses pemberian tindakan terhadap pelaku hanya untuk menghukum saja tidak ada proses untuk memperbaiki. Hak asasi manusia merupakan hak manusia, yang melekat pada manusia, dimana manusia juga dikaruniai akal pikiran serta hati nurani yang hal tersebut harus dilindungi oleh negara karena mengingat Indonesia berdasarkan Pasal 1 ayat (3) UUD NRI 1945 yang menjelaskan bahwa Indonesia merupakan negara hukum yang mana dalam negara hukum harus memegang teguh hak asasi manusia pula. Hak dalam hak asasi manusia mempunyai kedudukan atau derajat yang sama dan pertama dalam hidup bermasyarakat karena keberadaan hak asasi hakikatnya telah dimiliki dan melekat dalam individu manusia sejak dilahirannya. Seketika itu pula muncul kewajiban dari manusia lain untuk menghormatinya. Indonesia adalah negara yang masih mengakui adanya perlindungan Hak Asasi Manusia bagi seluruh rakyatnya sebagaimana tertuang dalam UUD 1945. Sehingga hukuman kebiri secara kimia dianggap tidak mendukung adanya perlindungan Hak Asasi Manusia. Karena kebiri kimia tersebut dianggap menurunkan harkat dan martabat bagi seseorang yang divonis hukuman kebiri kimia.

Penetapan hukuman kebiri kimia dapat dinyatakan sebagai salah satu hukuman yang dapat melanggar hak seseorang. Sehingga kebiri kimia ditolak oleh organisasi-organisasi yang menitik beratkan pada hak asasi manusia karena dasar-dasar pemikiran, yaitu pertama, kebiri kimia tidak dapat dinyatakan benar didalam sistim hukum pidana Indonesia Kedua, kebiri kimia dapat dinyatakan sebagai pelanggaran terhadap Hak Asasi Manusia yang terdapat didalam berbagai konvensi internasional yang telah diratifikasi oleh pemerintah diantaranya adalah Konvenan Hak Sipil dan Politik (ICCPR), Konvensi Anti Penyiksaan, dan Konvensi Hak Anak. Ketiga, setiap perbuatan yang menyiksa anak, termasuk salah satunya adalah kekerasan seksual.

Dari berbagai alasan-alasan yang telah dinyatakan oleh organisasi Hak Asasi Manusia, sehingga pemerintah diminta untuk fokus pada perlindungan anak dengan cara komprehensif dan menyeluruh, yang didalam kondisi tersebut anak adalah sebagai salah satu korban dari kekerasan seksual. Oleh karena itu pemerintah sebaiknya memberikan akses yang berguna serta menitik beratkan pada pemulihan fisik dan mental dari anak yang telah menjadi korban.

Didalam Pasal 5 Deklarasi Universal Hak Asasi Manusia tahun 1948 menyatakan "tidak seorang pun boleh disiksa atau diperlakukan secara kejam dan tidak manusiawi." Sedangkan dalam Pasal 28 I ayat (1) Undang-Undang Dasar Republik Indonesia menyatakan "setiap orang atau warga negara berhak untuk hidup, tidak mendapatkan penyiksaan, bebas dalam peikiran dan hati nurani, berhak beragama, tidak diperbudak, dituntut atas dasar hukum yang berlaku dan semua hak tersebut tidak dapat dikurangi ataupun dihilangkan dalam keadaan apapun oleh orang 
lain maupun warga negara itu sendiri." Sehingga hak-hak didalam pasal tersebut dapat ditegakkan maka masyarakat pun akan menghormati dan menghargai hak orang lain dan dapat meningkatkan kesejahteraan rakyat.

Pemberian zat antiandrogen kepada diri pelaku dianggap melanggar hak asasi manusia yang berupa penyiksaan secara fisik dan merendahkan martabat diri pelaku. Selain itu pemberian zat tersebut berefek samping berupa penuaan diri dan dapat mengurangi kepadatan tulang yang berakibat tulang keropos atau osteoporosis. Serta disisi lain zat antiandrogen dapat mengurangi masa otot yang dapat memperbesar tubuh menumpuk lemak dan kemudian dapat menimbulkan risiko penyakit jantung.

\section{SIMPULAN}

Kejahatan pelecehan seksual terhadap anak dianggap sebagai extra ordinary/serious crimes seperti korupsi, terorisme atau perdagangan narkotika. Hal ini dianggap apabila menjatuhkan hukuman seberat-beratnya merupakan solusi untuk menanggulangi kejahatan dikemudian hari dan mereka yang berpotensial menjadi pelaku kejahatan juga akan berupaya menahan diri agar tidak melakukan kejahatan yang serupa karena takut dihukum berat.

Menurut penulis bahwa sesungguhnya efek jera bukanlah dilihat dari hukuman yang berat, tetapi lebih kepada 3 hal yaitu: appropriate (proportionate punishment, punishment should fit the crime), prompt (promptness of punishment/celerity), and inevitable (certainty of punishment).

Hukuman kebiri kimia apabila diterapkan pada pelaku kejahatan seksual terhadap anak harus dengan cara berkali-kali disuntikkan terhadap pelaku agar hormon testosteron ditekan dan menjadi kadar yang rendah. Sehingga dapat menyebabkan kerusakan terhadap tubuh pelaku apabila terus menerus dilakukan. Oleh karena itu, hal tersebut tidak sesuai dengan apa yang dijaminkan terhadap Hak Asasi Manusia yang tercantum dalam pasal 28 I UUD NRI 1945, Deklarasi Hak asasi Manusia, dan ICCPR. Serta apabila penyuntikan tersebut dihentikan karena masa hukuman telah dijalani, maka tidak menjadi jaminan terhadap pelaku yang dapat mengulangi tindak pidana karena dorongan seksualnya telah kembali pulih.

Kita sepakat bahwa kejahatan pelecehan seksual terhadap anak merupakan kejahatan yang luar biasa dan sangat serius karena anak merupakan aset bagi bangsa dan negara untuk keberlangsungan hidup dalam masyarakat. Akan tetapi, penanggulangan kejahatan harus dilakukan secara rasional. Alangkah baiknya bahwa menggunakan hukum pidana yang bersifat non penal yang menitikberatkan pada sifat preventif atau pencegahan sebelum terjadinya tindak pidana kejahatan pelecehan seksual terhadap anak.

\section{DAFTAR PUSTAKA}

\section{Buku}

Gunadi, dan Oci Senjaya. Penologi dan Pemasyarakatan. Jakarta : PT. Adhi Sarana Nusantara, 2018.

Hamzah, Andi. Sistem Pidana dan Pemidanaan Indonesia. Jakarta : Pradnya Paramita, 1993.

Muladi dan Barda Nawawi Arief. Teori-Teori dan Kebijakan Pidana. Bandung : Alumni: 2008.

Salman, Otje, dan Anthon F. Susanto, Teori Hukum (Mengingat, Mengumpulkan, dan Membuka Kembali). Bandung : Refika Aditama, 2005.

Setiady, Tolib. Pokok-Pokok Hukum Penintesier Indonesia. Bandung : Alfabet, 2009.

Sunarso, Siswanto. Penegakan Hukum dalam Kajian Sosiologis. Jakarta : Raja Grafindo Persada, 2005.

\section{Jurnal}

Denni Dwi Putri Sitanggang, "Eksistensi Sanksi Kebiri Ditinjau dari Aspek Hak Asasi Manusia dan Kode Etik Kedokteran" terdapat dalam http://e- journal.uajy.ac.id/11192/1/JURNAL.pdf.

Ivo Naviana, "Kekerasan Seksual terhadap Anak : Dampak dan Penanganannya Child Sexual Abuse : Impact and Hendling.

Nuzul Qur'aini Mardiya, Penerapan Hukuman Kebiri Kimia Bagi Pelaku Kekerasan Seksual, Jurnal Konstitusi, Volume 14, Nomor 1, (Maret 2017).

\section{Peraturan Perundang-Undangan}

KUHP

KUHAP

Peraturan Pemerintah Nomor 70 Tahun 2020 tentang Tata Cara Pelaksanaan Tindakan Kebiri Kimia, Pemasangan Alat Pendeteksi Elektronik, Rehabilitasi, dan Pengumuman Identitas Pelaku Kekerasan Seksual Terhadap Anak.

Undang-Undang Nomor 17 Tahun 2016 tentang Penetapan Peraturan Pemerintah Pengganti Undang-Undang Nomor 1 Tahun 2016 tentang Perubahan Kedua atas Undang-Undang Nomor 23 Tahun 2002 tentang Perlindungan Anak. 
Nashru Nazar Rosyidi dan Oci Senjaya, Penerapan Penjatuhan Hukuman Kebiri Kimia Serta Tata Cara Eksekusinya pada Pelaku Kejahatan Pelecehan Seksual terhadap Anak

\section{Naskah Internet}

http://telusur.metrotvnews.com/news-telusur/8ko2rBrb-mencermati-kebiri-di-negara-lain ; diakses pada tanggal 23 November 2020

http://www.tribunnews.com/internasional/2016/05/27/ini-negara-negara-yang-berlakukan- hukuman-kebiri-bagipelaku-pelecehan ; diakses tanggal 22 November 2020

https://media.iyaa.com/article/2016/05/10-negara-terapkan-hukuman-kebiri-untuk-penjahat- seksual-3441985.html ; (diakses pada tanggal 23 November 2020

https://nasional.republika.co.id/berita/pww9mi384/hukum-kebiri-diterapkan-fahira-ini- peringatan-keras (diakses tanggal 22 November 2020 jam $21.31 \mathrm{WIB}$ )

https://www.cnnindonesia.com/gaya-hidup/20210104193518-255-589391/mengenal-kebiri- kimia-menghilangkanfungsi-testis-dan-libido 